\title{
Accuracy of the $n$-alkane technique for intake estimates in beef cattle using different sampling procedures and feeding levels
}

\author{
M. Oliván ${ }^{\mathrm{a}, *}$, L.M.M. Ferreira ${ }^{\mathrm{b}}$, R. Celaya ${ }^{\mathrm{a}}, \mathrm{K}$. Osoro ${ }^{\mathrm{a}}$ \\ a SERIDA-Servicio Regional de Investigación y Desarrollo Agroalimentario, Apdo 13, 33300 Villaviciosa, Asturias, Spain \\ ${ }^{\mathrm{b}}$ CECAV-Departamento de Zootecnia, Universidade de Trás-os-Montes e Alto Douro, PO Box 1013, 5000-911 Vila Real, Portugal
}

Received 19 December 2005; received in revised form 16 June 2006; accepted 27 June 2006

\begin{abstract}
The present study aimed to evaluate the reliability of the $n$-alkane technique for estimating herbage intake in beef cattle receiving two different feeding levels (low and high) and to test the effect of different faeces sampling procedures (total faeces samples or rectal grab samples at $8 \mathrm{~h}$ intervals) on the $n$-alkane faecal recoveries and hence on intake estimates. Two consecutive experiments were performed with 11 non-lactating beef cows of "Asturiana de los Valles" breed, fed with lucerne hay at two feeding levels: $1.0 \mathrm{or} 1.7 \mathrm{~kg}$ $\mathrm{DM} / 100 \mathrm{~kg}$ body weight (BW). Animals received a daily dose of paper pellets containing $\mathrm{C}_{24}, \mathrm{C}_{32}$ and $\mathrm{C}_{36} n$-alkanes as external markers with the purpose of using different $n$-alkane pairs of adjacent chain length $\left(\mathrm{C}_{23} / \mathrm{C}_{24}, \mathrm{C}_{25} / \mathrm{C}_{24}, \mathrm{C}_{31} / \mathrm{C}_{32}, \mathrm{C}_{33} / \mathrm{C}_{32}, \mathrm{C}_{35} / \mathrm{C}_{36}\right)$ for intake calculations. A 5-day equilibrium period was sufficient for external marker concentrations and $n$-alkane pair ratios to reach steady state in faeces. There was no effect of different sampling times (every $8 \mathrm{~h}$ ) on the faecal excretion of $n$-alkane pairs $\mathrm{C}_{31} / \mathrm{C}_{32}$ and $\mathrm{C}_{33} / \mathrm{C}_{32}$. Grab samples obtained at the time of dosing $(0830 \mathrm{~h})$ gave the best estimate of $n$-alkane pair ratios in total faeces collection. There was a general trend of increasing $n$-alkane faecal recoveries with increased chain length, although $n$-alkanes $\mathrm{C}_{30}, \mathrm{C}_{31}$ and $\mathrm{C}_{33}$ showed lower faecal recoveries than expected. $n$-Alkane recoveries were in general lower at the low feeding level, where an increase in individual variability of natural $n$-alkane recoveries was observed. At both feeding levels, the $n$-alkane pairs $\mathrm{C}_{23} / \mathrm{C}_{24}$ and $\mathrm{C}_{35} / \mathrm{C}_{36}$ gave accurate estimates of the treatment average intake, although the natural $n$-alkane $\left(\mathrm{C}_{23}\right.$ or $\left.\mathrm{C}_{35}\right)$ faecal recoveries showed high individual variability, which could be in part due to analytical bias caused by their extremely low concentration in the diet and faeces. However, the $n$-alkane pairs $\mathrm{C}_{31} / \mathrm{C}_{32}$ and $\mathrm{C}_{33} / \mathrm{C}_{32}$ gave the greatest deviations of intake estimates, due to the high discrepancy between the faecal recoveries of natural and dosed $n$-alkanes. These results demonstrate that in beef cattle, feeding level may have some influence on the relative faecal recoveries of the $n$-alkane pair used for intake calculations. This effect, together with the high individual variability of $n$-alkane recoveries, especially under low feeding level, may produce significant deviations of the individual intake estimates.
\end{abstract}

(C) 2006 Elsevier B.V. All rights reserved.

Keywords: Feeding level; Beef cattle; $n$-Alkanes; Intake

* Corresponding author. Tel.: +34 98 5890066; fax: +34 985891854.
E-mail address: mcolivan@serida.org (M. Oliván).

\section{Introduction}

It is widely accepted that the $n$-alkane technique is an accurate method to estimate herbage intake by grazing ruminants. In spite of the incomplete recovery of $n$-alkanes in faeces, the concurrent use of two $n$-alkanes of adjacent chain length, a dietary natural odd-chain $n$-alkane and a 
dosed synthetic even-chain $n$-alkane, essentially as internal and external markers, respectively, allows unbiased estimates of intake provided that diet and dosed $n$-alkanes have similar faecal recoveries (Dove and Mayes, 1991, 1996; Mayes and Dove, 2000).

The use of this method raises similar issues to those of any other technique based on markers, such as obtaining representative samples of consumed herbage and faeces, accurate administration of external marker, kinetics of internal and external marker flow and diurnal pattern of faecal excretion.

To date, crucial aspects like the effect of carrier matrix or dosing method and frequency on the excretion kinetics of the dosed $n$-alkanes have been studied (Dove et al., 2002; Molina et al., 2004; Giráldez et al., 2004). Furthermore, it has been shown that the characteristics of the diet, in terms of nutritive value or number of components, may influence the recovery of dosed and naturally occurring $n$-alkanes (Ferreira et al., 2005).

While there is extensive evidence of successful use of the $n$-alkane technique to estimate intake in sheep (Mayes et al., 1986; Dove et al., 2000) and dairy cattle (Dillon and Stakelum, 1989; Unal and Garnsworthy, 1999) there is still little information about the accuracy of this method in beef cattle. Moreover, there is a lack of information on whether the level of intake and the resulting changes in digestive kinetics of natural and dosed $n$-alkanes may influence the $n$-alkane faecal recoveries and hence may affect the accuracy of herbage intake estimates under beef cattle feeding conditions.

The aim of the current study was to evaluate the effect of the level of feeding on faecal $n$-alkane recoveries and the representativeness of faecal grab sampling, and the effects of these on the accuracy of intake estimation in beef cattle.

\section{Materials and methods}

This study was conducted at the facilities of Servicio Regional de Investigación y Desarrollo Agroalimentario (SERIDA) in Villaviciosa, Asturias, Spain (latitude $43^{\circ} 29^{\prime}$, longitude $-5^{\circ} 26^{\prime}$ ), using “Asturiana de los Valles" beef cows housed in metabolism crates.

\subsection{Animals and diets}

Two consecutive experiments were conducted with eleven non-lactating and non-pregnant mature beef cows. Each cow was fed $1.057 \mathrm{~kg} \mathrm{DM} / 100 \mathrm{~kg}$ body weight (low feeding level "LF") and $1.716 \mathrm{~kg} \mathrm{DM} /$ $100 \mathrm{~kg}$ body weight (high feeding level "HF") in the first and in the second trial, respectively, corresponding to 1.17 and 1.90 of the energy maintenance requirements of these cows (AFRC, 1993). The initial mean body weight (BW) of animals was $484 \pm 26 \mathrm{~kg}$ and $481 \pm 27 \mathrm{~kg}$ in the first and in the second experiment, respectively.

The diet used in these trials consisted of lucerne hay as the sole feed, supplied in individual mangers in order to measure individual intakes. Animals were fed equal portions twice daily at 0830 and $1630 \mathrm{~h}$ and had free access to water. Urinary collectors were inserted in all cows to avoid contamination of faeces.

\subsection{Experiment 1: low feeding level " $L F$ "}

There was a preliminary period of 7 days for adaptation of cows to the diet and experimental conditions followed by an experimental period of 12 days. From days 1 to 11 of the experimental period animals were dosed once daily at $0830 \mathrm{~h}$ with a paper pellet containing 931.4 \pm 1.69 (mean \pm S.E.) $\mathrm{mg}$ of $n$-alkane $\mathrm{C}_{24}$ ( $n$-tetracosane), $880.6 \pm$ $1.60 \mathrm{mg}$ of $n$-alkane $\mathrm{C}_{32}$ (n-dotriacontane) and $846.4 \pm$ $1.54 \mathrm{mg}$ of $n$-alkane $\mathrm{C}_{36}$ ( $n$-hexatriacontane). These synthetic $n$-alkanes (>99\% pure, Sigma-Aldrich Corp., St. Louis, MO, USA) were absorbed into shredded paper (Whatman No 1 filter paper) following the procedure of Mayes et al. (1986). During this experimental period, total faecal output and herbage dry matter intake were individually recorded daily. Six samples of offered herbage were taken daily for $n$-alkane analysis and subsampled for dry matter determination. The presence of individual refusals was checked daily before the morning feeding. Total faecal production was collected daily from days 2 to 12 , in order to monitor the $n$-alkane excretion and hence to determine the time necessary to reach a steady-state output of the markers. The effect of different sampling times on $n$-alkane faecal excretion was studied from days 8 to 11 , by collecting rectal grab samples $( \pm 200 \mathrm{~g} \mathrm{DM})$ at $8 \mathrm{~h}$ intervals: $0830 \mathrm{~h}(\mathrm{G} 1), 1630 \mathrm{~h}(\mathrm{G} 2)$ and $0030 \mathrm{~h}(\mathrm{G} 3)$. The relationships between the concentration of natural and dosed $n$-alkanes and the $n$ alkane pair (natural/dosed) ratios in these grab samples and in total faeces samples were studied.

Herbage intake was estimated from the content of n-alkane pairs $\mathrm{C}_{23} / \mathrm{C}_{24}, \mathrm{C}_{25} / \mathrm{C}_{24}, \mathrm{C}_{31} / \mathrm{C}_{32}, \mathrm{C}_{33} / \mathrm{C}_{32}$ and $\mathrm{C}_{35} / \mathrm{C}_{36}$ in total faeces and herbage in the last 4 days.

\subsection{Experiment 2: high feeding level " $H F$ "}

Immediately after Experiment 1, and under the same conditions, cows were used in a second trial, where they were fed with the same diet (lucerne hay) but the feeding level was increased from 1.06 to $1.72 \mathrm{~kg} \mathrm{DM} / 100 \mathrm{~kg}$ live 
weight. There was a period of 7 days for adaptation of cows to the increased level of intake followed by an experimental period of 7 days. Animals received, both during the adaptation and the experimental period, a daily dose of synthetic $n$-alkanes at $0830 \mathrm{~h}$ with a paper pellet containing $928.2 \pm 2.76 \mathrm{mg} \mathrm{of}_{24}, 873.9 \pm 2.60 \mathrm{mg}$ of $\mathrm{C}_{32}$ and $824.1 \pm 2.45 \mathrm{mg}$ of $\mathrm{C}_{36}$.

Daily weights of offered diet and faecal production were recorded, from days 1 to 7 of the experimental period. Six samples of offered herbage were taken daily for $n$-alkane analysis and subsampled for dry matter determination. Feed refusals were collected daily before morning feeding, weighed, subsampled for dry matter content and then bulked for each cow. These refusals were taken into account in the faecal recovery and intake calculations.

In this experiment, the effect of different sampling times on $n$-alkane faecal excretion was studied from days 3 to 6 , by collecting rectal grab samples at $8 \mathrm{~h}$ intervals: $0830 \mathrm{~h}(\mathrm{G} 1), 1630 \mathrm{~h}(\mathrm{G} 2)$ and $0030 \mathrm{~h}(\mathrm{G} 3)$. The relationships between the concentration of natural and dosed $n$-alkanes and the $n$-alkane pair (natural/dosed) ratios in these grab samples and in total faeces samples were studied.

Daily intake was estimated from the content of $n$-alkane pairs $\mathrm{C}_{23} / \mathrm{C}_{24}, \mathrm{C}_{25} / \mathrm{C}_{24}, \mathrm{C}_{31} / \mathrm{C}_{32}, \mathrm{C}_{33} / \mathrm{C}_{32}$ and $\mathrm{C}_{35} / \mathrm{C}_{36}$ in total faeces and herbage in the last 4 days.

\subsection{Analytical}

In both experiments, all samples of herbage, feed refusals and faeces were frozen at $-20{ }^{\circ} \mathrm{C}$ until required for analysis, then freeze-dried and ground to pass a $1-\mathrm{mm}$ screen. All herbage and faecal samples were sub-sampled for dry matter determination by drying at $80^{\circ} \mathrm{C}$ in a forced-air oven until constant weight.

Samples of the diet were analysed in duplicate for chemical composition. Ash (ID 942.05) and nitrogen (ID 954.01) were determined by methods proposed by AOAC (1990). Neutral detergent fibre (NDF), acid detergent fibre (ADF) and acid detergent lignin (ADL) were analysed by the method of Robertson and Van Soest (1981) and Van Soest et al. (1991). Hemicellulose and cellulose were calculated as the difference between NDF and $\mathrm{ADF}$ and $\mathrm{ADF}$ and $\mathrm{ADL}$, respectively.

$n$-Alkane contents of individual samples of lucerne hay and faeces were analysed in duplicate according to the method of Mayes et al. (1986) with minor modifications (Oliván and Osoro, 1999). The first stage involved a treatment of $0.5 \mathrm{~g}$ of faeces or $1.5 \mathrm{~g}$ lucerne hay for $14 \mathrm{~h}$ in $7 \mathrm{~mL}$ ethanolic $1 \mathrm{M} \mathrm{KOH}$ (Merck, Germany) at $90{ }^{\circ} \mathrm{C}$, followed by a hot extraction performed with $n$-heptane
(Merck, Germany) at $65{ }^{\circ} \mathrm{C}$. After the extraction, the sample was passed through a silica-gel (Merck, Germany) column of $5 \mathrm{~mL}$ (Alltech Associates, Illinois, USA), evaporated to dryness and redissolved in $500 \mu \mathrm{L}$ heptane for chromatographic analysis.

The $n$-alkane content of the dosed pellets was determined on 5 pellets randomly selected from each experimental trial. Five replicates of $1 \mathrm{~g}$ were extracted in a Soxhlet extractor using $100 \mathrm{~mL}$ of petroleum spirit (B.P. $60-80{ }^{\circ} \mathrm{C}$, Merck, Germany) after weighing $100 \mathrm{mg}$ of $\mathrm{C}_{22}$ and $\mathrm{C}_{34}$ (>99\% pure, Sigma-Aldrich Corp., St. Louis, MO, USA) as internal standards. A $20 \mathrm{~mL}$ aliquot of the extract was evaporated to dryness, redissolved in $500 \mu \mathrm{L}$ heptane and submitted to the same analytical procedures as the dietary and faecal extracts.

Quantification of the $n$-alkanes was carried out by gas chromatography, using a VARIAN 3400 gas chromatograph (Varian Inc., Palo Alto, CA, USA), equipped with flame ionisation detector (FID), an 8200 autosampler and a temperature-programmable (SPI) injector. n-Alkane extracts were injected $(0.5 \mu \mathrm{L})$ by on-column injection onto a 15-m DB-1 megabore column (J and W Scientific, USA) of $0.530 \mathrm{~mm}$ internal diameter and $1.5 \mu \mathrm{m}$ film thickness. Helium was used as carrier gas at a constant flow of $15 \mathrm{~mL} / \mathrm{min}$. Gradients of temperature were used for the injector $\left(80^{\circ} \mathrm{C}\right.$ for $0.2 \mathrm{~min} ; 200 \mathrm{~K} / \mathrm{min}$ to $380^{\circ} \mathrm{C}$ ) and the column $\left(200{ }^{\circ} \mathrm{C}\right.$ for $1 \mathrm{~min} ; 6 \mathrm{~K} / \mathrm{min}$ to $300{ }^{\circ} \mathrm{C}$; $6 \mathrm{~min}$ at $300^{\circ} \mathrm{C}$ ). The detector oven was maintained at $350{ }^{\circ} \mathrm{C}$.

Gas chromatographic (GC) procedures were calibrated with a standard solution containing a mixture of synthetic $n$-alkanes (from $\mathrm{C}_{23}$ to $\mathrm{C}_{36}$ ) ( $>99 \%$ pure, Sigma-Aldrich Corp., St. Louis, MO, USA) with similar concentrations to those found in extracts. The response factors for individual $n$-alkanes were calculated from peak areas and the known concentrations. n-Alkane concentrations were quantified relative to known amounts of the internal standards $\mathrm{C}_{22}$ and $\mathrm{C}_{34}$, added at the beginning of the extraction process. The ratio of the peak areas of the internal standards obtained in every chromatogram was compared with the actual ratio added in the standard solution to check the effectiveness of the extraction process, and all peak areas were corrected for any observed discrimination, which was assumed to be linear depending upon the chain length of the $n$-alkanes, as shown by Oliván and Osoro (1999).

\subsection{Calculations}

In vivo dry matter digestibility (DMD) of the diet was calculated for each cow $(n=11)$ during the last 4 days of 
each experiment (LF and HF) using mean diet intake ( $I$, $\mathrm{kg}$ /day DM) and mean faecal output (FO, $\mathrm{kg} \mathrm{DM}$ /day):

$\mathrm{DMD}=\left(1-\frac{\mathrm{FO}}{I}\right) \times 1000$

The faecal recovery of each $n$-alkane was calculated as the proportion of $n$-alkane consumed in the diet (natural) or paper pellet (dosed) which was recovered in the faeces.

Herbage dry matter intake was estimated from the ratio of naturally occurring and dosed $n$-alkanes $\left(\mathrm{C}_{23} /\right.$ $\left.\mathrm{C}_{24}, \mathrm{C}_{25} / \mathrm{C}_{24}, \mathrm{C}_{31} / \mathrm{C}_{32}, \mathrm{C}_{33} / \mathrm{C}_{32}, \mathrm{C}_{35} / \mathrm{C}_{36}\right)$ in lucerne hay and faeces samples, according to the equation proposed by Mayes et al. (1986) and expressed below in a simplified version:

Herbage intake $(\mathrm{kg} \mathrm{DM} /$ day $)=\frac{D_{j}}{\frac{F_{j}}{F_{i}} * H_{i}-H_{j}}$

where $D_{j}$ is the daily dose $(\mathrm{mg})$ of synthetic alkanes $\mathrm{C}_{24}$, $\mathrm{C}_{32}$ or $\mathrm{C}_{36}$ in paper pellets, $F_{i}$ and $H_{i}$ are the respective concentrations ( $\mathrm{mg} / \mathrm{kg} \mathrm{DM}$ ) of $\mathrm{C}_{23}, \mathrm{C}_{25}, \mathrm{C}_{31}, \mathrm{C}_{33}$ or $\mathrm{C}_{35}$ in faeces and herbage (lucerne hay) and $F_{j}$ and $H_{j}$ are the respective concentrations $(\mathrm{mg} / \mathrm{kg} \mathrm{DM})$ of $\mathrm{C}_{24}, \mathrm{C}_{32}$ or $\mathrm{C}_{36}$ in faeces and herbage (lucerne hay).

\subsection{Statistical analysis}

Statistical analyses were performed using SPSS (SPSS Inc., Ireland version $11.5,2002)$. The $n$-alkane excretion curve was studied by comparing the concentration of external markers $\left(\mathrm{C}_{24}, \mathrm{C}_{32}\right.$ and $\left.\mathrm{C}_{36}\right)$ and $n$-alkane pair ratios $\left(\mathrm{C}_{23} / \mathrm{C}_{24}, \mathrm{C}_{25} / \mathrm{C}_{24}, \mathrm{C}_{31} / \mathrm{C}_{32}, \mathrm{C}_{33} / \mathrm{C}_{32}, \mathrm{C}_{35} / \mathrm{C}_{36}\right)$ in the total faeces samples obtained each day with the mean for subsequent days, using analysis of variance. The relationships between the concentration of $n$-alkanes (natural and dosed) and the $n$-alkane pair (natural/dosed) ratios in total faeces samples and in grab samples taken every $8 \mathrm{~h}(0830$, 1630 and $0030 \mathrm{~h}$ ) were assessed by linear regression. Since $y$-intercepts never differed significantly from zero, all regressions were constrained through zero. All regressions were performed using the values obtained for each animal $(n=11)$.

The effect of feeding level (low or high) and animal (1 to 11 ) and their interaction on the $n$-alkane faecal recoveries and intake estimates were assessed by analysis of variance. Since there was no significant interaction feeding level $\times$ animal, the final model included the fixed effects of feeding level and animal:

$$
y_{i j}=\mu+\text { FEEDING LEVEL }_{i}+\text { ANIMAL }_{j}+e_{i j}
$$

In this model $y_{i j}=$ dependent variable ( $n$-alkane faecal recoveries, intake estimates with different $n$-alkane pairs: $\mathrm{C}_{23} / \mathrm{C}_{24}, \mathrm{C}_{25} / \mathrm{C}_{24}, \mathrm{C}_{31} / \mathrm{C}_{32}, \mathrm{C}_{33} / \mathrm{C}_{32}, \mathrm{C}_{35} / \mathrm{C}_{36}$ ), $\mu=$ general mean, FEEDING $\mathrm{LEVEL}_{i}=$ main feeding level effect $(i=1,2), \mathrm{ANIMAL}_{j}=$ main animal effect $(j=1,2 \ldots, 11)$ and $e_{i j}=$ residual random term.

Estimated herbage intake, calculated with different n-alkane pairs $\left(\mathrm{C}_{23} / \mathrm{C}_{24}, \mathrm{C}_{25} / \mathrm{C}_{24}, \mathrm{C}_{31} / \mathrm{C}_{32}, \mathrm{C}_{33} / \mathrm{C}_{32}, \mathrm{C}_{35} /\right.$ $\mathrm{C}_{36}$ ) were compared with observed intake using Student's $t$-test for paired comparisons.

\section{Results and discussion}

\subsection{Chemical composition of the diet}

The chemical composition of the lucerne hay supplied to the animals (Table 1) was similar in Experiment 1 (low feeding level: LF) and Experiment 2 (high feeding level: $\mathrm{HF}$ ), as the lucerne bales were randomly selected from a same feeding batch. Moreover, the results of in vivo DMD of the diet calculated in each trial showed that, despite the differences in feeding level, there were no significant differences of diet digestibility between the low feeding (595 g/kg DM) and the high feeding (598 g/ $/ \mathrm{kg} \mathrm{DM})$ experiments.

\section{2. n-Alkane concentrations of diet}

Table 2 shows the $n$-alkane concentrations of the lucerne hay supplied in both experiments (LF and HF). The concentrations of $\mathrm{C}_{22}$ and $\mathrm{C}_{34}$ are not presented as they were added to samples at the beginning of the analysis as internal standards for GC analysis.

The odd-chain $n$-alkanes comprised the highest fraction representing more than 0.93 of the total $n$-alkane content. Some plant $n$-alkanes, particularly $\mathrm{C}_{23}, \mathrm{C}_{25}, \mathrm{C}_{26}$ and $\mathrm{C}_{35}$ had very low concentrations, which could limit

Table 1

Chemical composition and in vivo dry matter digestibility (DMD) of the lucerne hay $(\mathrm{g} / \mathrm{kg} \mathrm{DM})$ offered in the low (LF) and high (HF) feeding experiments (means \pm S.E.M.)

\begin{tabular}{llr}
\hline Lucerne hay & \multicolumn{2}{l}{ Level of feeding } \\
\cline { 2 - 3 } & Low (LF) & High (HF) \\
\hline Organic matter & $894 \pm 2.6$ & $904 \pm 1.6$ \\
Crude protein & $175 \pm 4.3$ & $162 \pm 3.3$ \\
$\mathrm{NDF}^{\mathrm{a}}$ & $476 \pm 13.6$ & $468 \pm 5.1$ \\
$\mathrm{ADF}$ & $356 \pm 9.1$ & $363 \pm 6.2$ \\
$\mathrm{ADL}$ & $74 \pm 2.1$ & $78 \pm 1.5$ \\
Cellulose & $282 \pm 7.7$ & $285 \pm 4.9$ \\
Hemicellulose & $137 \pm 7.6$ & $122 \pm 4.6$ \\
In vivo DMD & $595 \pm 9.0$ & $598 \pm 5.0$ \\
\hline
\end{tabular}

${ }^{\text {a }} \mathrm{NDF}$ ash free, assayed without sodium sulphite. 
Table 2

Concentration of $n$-alkanes in the lucerne hay $(\mathrm{mg} / \mathrm{kg} \mathrm{DM})$ and paper pellets (mg) used in the low (LF) and high (HF) feeding experiments (means \pm S.E.M.)

\begin{tabular}{lcc}
\hline & Level of feeding & \\
\cline { 2 - 3 } & Low (LF) & High (HF) \\
\hline Lucerne hay & & \\
$\mathrm{C}_{23}$ & $1.4 \pm 0.07$ & $0.9 \pm 0.04$ \\
$\mathrm{C}_{24}$ & $1.5 \pm 0.06$ & $1.4 \pm 0.04$ \\
$\mathrm{C}_{25}$ & $6.1 \pm 0.26$ & $6.4 \pm 0.21$ \\
$\mathrm{C}_{26}$ & $3.0 \pm 0.08$ & $2.9 \pm 0.06$ \\
$\mathrm{C}_{27}$ & $26.0 \pm 0.77$ & $28.5 \pm 0.61$ \\
$\mathrm{C}_{28}$ & $12.4 \pm 0.28$ & $13.0 \pm 0.24$ \\
$\mathrm{C}_{29}$ & $146.5 \pm 4.61$ & $155.6 \pm 3.82$ \\
$\mathrm{C}_{30}$ & $21.7 \pm 0.47$ & $21.6 \pm 0.42$ \\
$\mathrm{C}_{31}$ & $599.0 \pm 15.67$ & $652.0 \pm 14.01$ \\
$\mathrm{C}_{32}$ & $20.3 \pm 0.47$ & $18.6 \pm 0.34$ \\
$\mathrm{C}_{33}$ & $60.5 \pm 1.73$ & $50.9 \pm 1.27$ \\
$\mathrm{C}_{35}$ & $2.7 \pm 0.36$ & $0.7 \pm 0.03$ \\
$\mathrm{C}_{36}$ & $2.0 \pm 0.05$ & $2.2 \pm 0.03$ \\
& & \\
Pellets & & $928.2 \pm 2.76$ \\
$\mathrm{C}_{24}$ & $931.4 \pm 1.69$ & $873.9 \pm 2.60$ \\
$\mathrm{C}_{32}$ & $880.6 \pm 1.60$ & $824.1 \pm 2.45$ \\
$\mathrm{C}_{36}$ & $846.4 \pm 1.54$ &
\end{tabular}

their use for $n$-alkane recovery and/or intake calculations. The content of $\mathrm{C}_{24}$ and $\mathrm{C}_{36}$ in the diet was also extremely low ( $\leq 2.2 \mathrm{mg} / \mathrm{kg} \mathrm{DM})$, which is the reason for using $\mathrm{C}_{24}$ and $\mathrm{C}_{36}$ as external markers as their presence in plants is almost negligible.

The $n$-alkane concentrations of the lucerne hay were similar to those described in previous reports for this plant species (Malossini et al., 1990; Hendricksen et al., 2002), although in our study the mean concentrations of most $n$-alkanes were higher, in particular those of $\mathrm{C}_{31}$, $\mathrm{C}_{32}$ and $\mathrm{C}_{33}$.

In Experiment 1, with low feeding level, there were no feed refusals. However, in the course of Experiment 2,

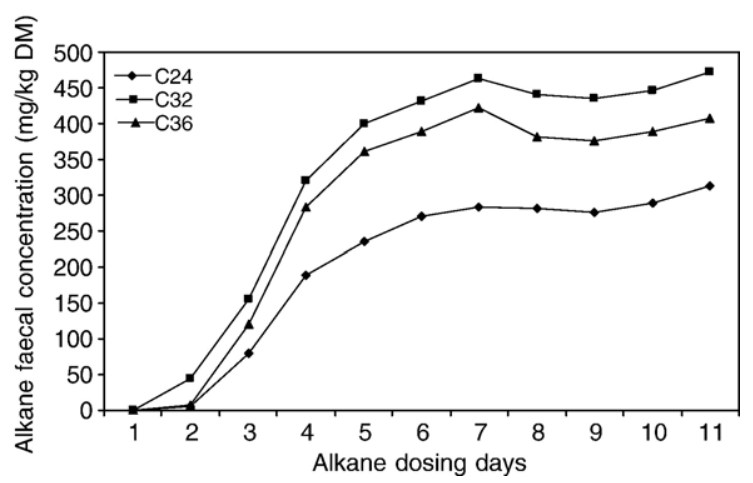

Fig. 1. Increase with time in the concentration of dosed alkanes $\left(\mathrm{C}_{24}\right.$, $\mathrm{C}_{32}$ and $\mathrm{C}_{36}$ ) in samples of total faeces collection in Experiment 1 (LF). with a higher feeding level, four animals had small amounts of feed refusals, which showed the same $n$-alkane pattern as the offered diet (data not shown).

\section{3. n-Alkane excretion equilibrium}

The evolution of the faecal excretion of dosed $n$-alkanes $\left(\mathrm{C}_{24}, \mathrm{C}_{32}\right.$ and $\left.\mathrm{C}_{36}\right)$ along the dosing period was studied in the $\mathrm{LF}$ experiment, in order to detect the minimum dosing time required to reach a steady excretion pattern. Fig. 1 shows the evolution of the concentration of dosed $n$-alkanes in samples of total faeces collection. Comparisons of faecal excretion of external markers for each day with the mean for subsequent days were used to assess when the excretion of dosed $n$-alkanes reached equilibrium, as proposed by Molina et al. (2004). Alkanes $\mathrm{C}_{24}$ and $\mathrm{C}_{32}$ in faeces reached a steady state on day 5 , as faecal alkane concentrations on day 5 versus days 6 to 11 and on day 6 versus days 7 to 11 did not differ. However, only 4 days were necessary for $n$-alkane $\mathrm{C}_{36}$ to reach a steady concentration in faeces. This agrees with results obtained by Molina et al. (2004) who found that in cows 4 to 5 days were necessary for dosed $n$-alkanes to reach equilibrium in faeces when dosing $n$-alkanes with a controlled release device (CRD) or gelatin capsules, respectively. Similar results were obtained by Dove et al. (2002) when dosing sheep with $C_{36}$ using the same matrix (paper pellet) and dosing frequency (once daily). In fact, these authors observed a more rapid rise of $\mathrm{C}_{36}$ faecal concentrations when compared with faecal concentrations of $\mathrm{C}_{28}$ and $\mathrm{C}_{32}$ dosed via controlled release devices (CRD).

For intake estimation, the ratios of dosed and natural $n$-alkanes in faeces are more important, rather than absolute concentrations. Our results show that all studied ratios $\left(\mathrm{C}_{23} / \mathrm{C}_{24}, \mathrm{C}_{25} / \mathrm{C}_{24}, \mathrm{C}_{31} / \mathrm{C}_{32}, \mathrm{C}_{33} / \mathrm{C}_{32}, \mathrm{C}_{35} / \mathrm{C}_{36}\right)$ reached a steady state in 5 days. This agrees with most previous studies performed in sheep or cattle with different dosing procedures, such as paper pellets, gelatin capsules or CRD, that propose 5 to 6 days as the period necessary for $n$-alkane ratios to reach a steady excretion pattern (Mayes et al., 1986; Dove et al., 1989; Hendricksen et al., 2002).

\section{4. n-Alkane excretion pattern}

After the $n$-alkane excretion reaches a steady situation, the main concern is whether there is a diurnal variation in the alkane faecal excretion. The $n$-alkane concentrations of grab samples obtained every $8 \mathrm{~h}$ during an $88 \mathrm{~h}$ period (4 days) were used to assess the variability of $n$-alkane excretion throughout the day. Fig. 2 shows the evolution 

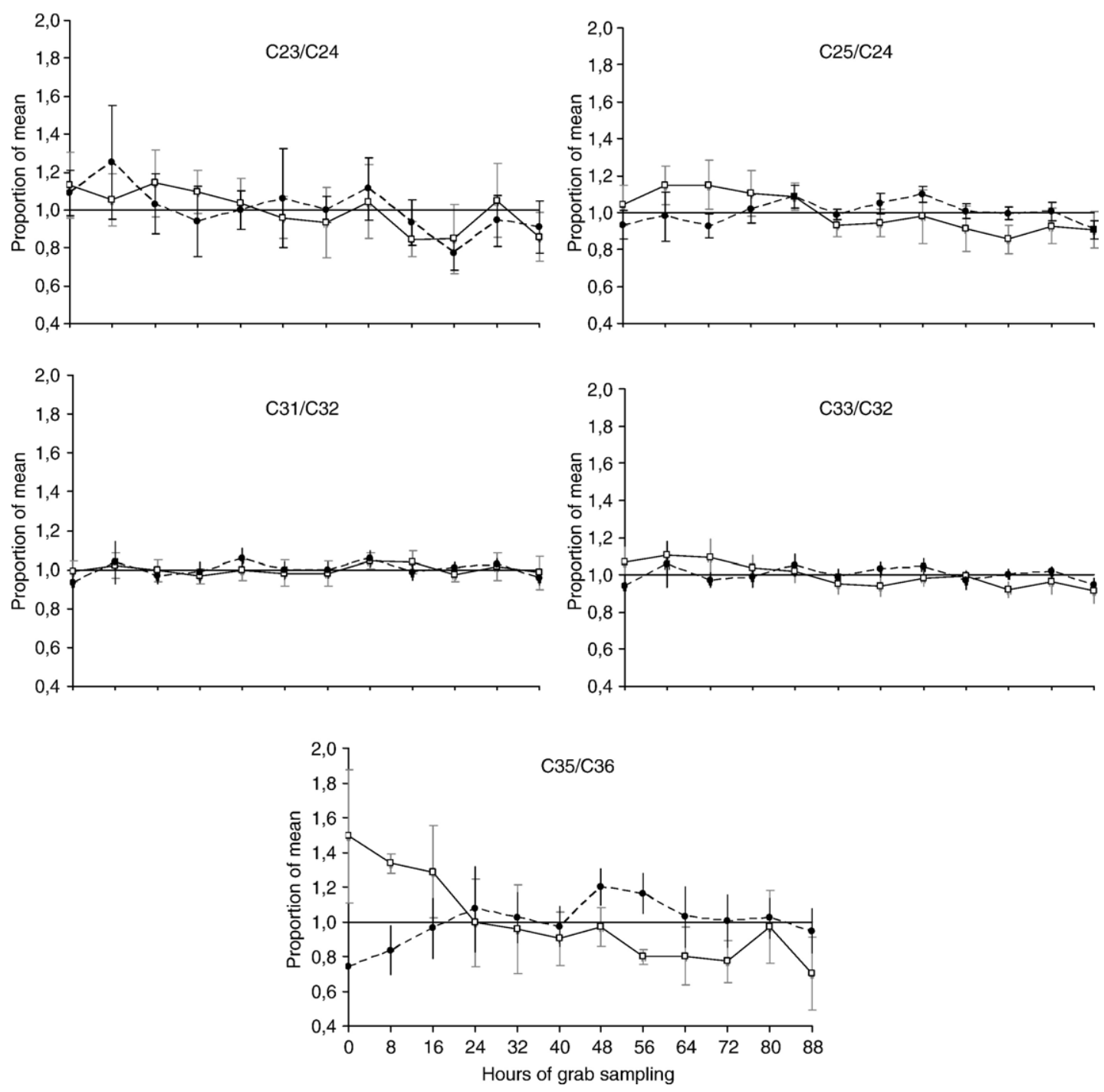

Fig. 2. Temporal changes in the ratio of natural to dosed alkane pairs $\left(\mathrm{C}_{23} / \mathrm{C}_{24}, \mathrm{C}_{25} / \mathrm{C}_{24}, \mathrm{C}_{31} / \mathrm{C}_{32}, \mathrm{C}_{33} / \mathrm{C}_{32}, \mathrm{C}_{35} / \mathrm{C}_{36}\right)$ in grab samples, expressed as a proportion of the mean ratio, in animals receiving low (- $\square-)$ and high (-

feeding level. Vertical bars show $95 \%$ confidence intervals.

of the main $n$-alkane pair ratios (natural/dosed) in grab samples in experiments 1 (LF) and 2 (HF), that is, under low and high feeding levels. The $n$-alkane ratios $\left(\mathrm{C}_{23} / \mathrm{C}_{24}\right.$, $\left.\mathrm{C}_{25} / \mathrm{C}_{24}, \mathrm{C}_{31} / \mathrm{C}_{32}, \mathrm{C}_{33} / \mathrm{C}_{32}, \mathrm{C}_{35} / \mathrm{C}_{36}\right)$ at each individual time are expressed as proportions of the mean ratio of the whole sampling period for each cow. Each point represents a mean of 11 values (i.e. cows). The pattern of excretion of the $n$-alkane pairs $\mathrm{C}_{31} / \mathrm{C}_{32}$ and $\mathrm{C}_{33} / \mathrm{C}_{32}$ was very constant in both the low (LF) and high (HF) feeding treatments, showing a maximum coefficient of variation $(\mathrm{CV})$ of $13 \%$ in the $\mathrm{LF}$ and $14 \%$ in the HF trials. Furthermore, for these $n$-alkane pairs there was no evidence of diurnal variation of $n$-alkane excretion as in all points unity was included in the $95 \%$ confidence interval (see Fig. 2). This agrees with the results obtained by Mayes et al. (1986) who did not find any diurnal variation in faecal $n$-alkane ratios $\mathrm{C}_{31} / \mathrm{C}_{32}$ and $\mathrm{C}_{33} / \mathrm{C}_{32}$ when dosing sheep once-daily with $n$-alkane paper pellets containing $\mathrm{C}_{28}$ and $\mathrm{C}_{32} n$-alkanes.

However, the diurnal variation of excretion was higher for $n$-alkane pairs $\mathrm{C}_{23} / \mathrm{C}_{24}, \mathrm{C}_{25} / \mathrm{C}_{24}$ and $\mathrm{C}_{35} / \mathrm{C}_{36}$, especially for $\mathrm{C}_{23} / \mathrm{C}_{24}$ (CV up to $32 \%$ in $\mathrm{LF}$ and $36 \%$ in $\mathrm{HF}$ trials) and $\mathrm{C}_{35} / \mathrm{C}_{36}$ pairs (CV up to $40 \%$ in $\mathrm{LF}$ and $34 \%$ in $\mathrm{HF}$ treatments). This could be due to analytical bias derived from the extremely low concentration of $n$-alkanes $\mathrm{C}_{23}$ and $\mathrm{C}_{35}$ in the $\operatorname{diet}\left(\mathrm{C}_{23}<1.5 \mathrm{mg} / \mathrm{kg} \mathrm{DM}\right.$ and $\mathrm{C}_{35} \leq 2.7 \mathrm{mg} / \mathrm{kg}$ $\mathrm{DM}$, Table 2) and faeces $\left(\mathrm{C}_{23}<2.5 \mathrm{mg} / \mathrm{kg} \mathrm{DM}\right.$ and $\mathrm{C}_{35} \leq 5.5 \mathrm{mg} / \mathrm{kg} \mathrm{DM}$, Table 3). 
Table 3

Concentration of $n$-alkanes ( $\mathrm{mg} / \mathrm{kg} \mathrm{DM})$ in total faeces in the low (LF) and high (HF) feeding experiments (means \pm S.E.M.)

\begin{tabular}{lcr}
\hline & Level of feeding & \\
\cline { 2 - 3 } & Low (LF) & High (HF) \\
\hline $\mathrm{C}_{23}$ & $2.4 \pm 0.13$ & $1.4 \pm 0.06$ \\
$\mathrm{C}_{24}$ & $301.3 \pm 9.44$ & $201.3 \pm 5.39$ \\
$\mathrm{C}_{25}$ & $10.9 \pm 0.25$ & $12.0 \pm 0.15$ \\
$\mathrm{C}_{26}$ & $6.0 \pm 0.14$ & $6.5 \pm 0.16$ \\
$\mathrm{C}_{27}$ & $54.4 \pm 0.75$ & $59.5 \pm 0.67$ \\
$\mathrm{C}_{28}$ & $28.6 \pm 0.37$ & $28.4 \pm 0.53$ \\
$\mathrm{C}_{29}$ & $323.2 \pm 4.80$ & $344.6 \pm 3.46$ \\
$\mathrm{C}_{30}$ & $45.4 \pm 0.54$ & $44.1 \pm 0.58$ \\
$\mathrm{C}_{31}$ & $1089.6 \pm 15.12$ & $1198.0 \pm 10.17$ \\
$\mathrm{C}_{32}$ & $463.3 \pm 12.51$ & $303.6 \pm 7.27$ \\
$\mathrm{C}_{33}$ & $113.4 \pm 1.73$ & $95.1 \pm 0.98$ \\
$\mathrm{C}_{35}$ & $5.5 \pm 0.36$ & $2.1 \pm 0.08$ \\
$\mathrm{C}_{36}$ & $401.1 \pm 11.60$ & $269.5 \pm 7.02$ \\
\hline
\end{tabular}

Also, it must be taken into account that for $n$-alkane pairs $\mathrm{C}_{23} / \mathrm{C}_{24}$ and $\mathrm{C}_{35} / \mathrm{C}_{36}$ there was a great difference between the low concentration in the diet of natural $n$-alkanes $\mathrm{C}_{23}(0.9$ to $1.4 \mathrm{mg} / \mathrm{kg} \mathrm{DM})$ and $\mathrm{C}_{35}$ ( 0.7 to $2.7 \mathrm{mg} / \mathrm{kg} \mathrm{DM}$ ) and the high amount of synthetic n-alkanes $\mathrm{C}_{24}$ and $\mathrm{C}_{36}$ ( 824 to $931 \mathrm{mg}$ ) received daily by animals in the paper pellet. This discrepancy could produce differences in the relative absorbance of natural and dosed $n$-alkanes along the digestive tract and thus a higher diurnal variation in the excretion of these $n$-alkane pairs. In fact, the incomplete mixing of the marker with ruminal contents has been considered as the main factor responsible for the diurnal fluctuations of faecal marker concentrations (Dillon and Stakelum, 1989; Owens and Hanson, 1992). Similar results were obtained by Dove et al. (2002) who found in sheep marked variation with time in $\mathrm{C}_{36}$ faecal concentrations and thus in the $\mathrm{C}_{35} / \mathrm{C}_{36}$ ratio.

It is obvious that the excretion pattern of $n$-alkane pairs to be used for intake calculation may be affected by the dosing method (timing and $n$-alkane carrier matrix) and the behaviour of the digesta in the digestive tract. Thus, different carrier matrices and dosing schedules should be used depending on the type of feeding pattern and diet. Giráldez et al. (2004) studied the effect of different carrier matrices (cellulose powder, paper bungs, paper filters, shredded filter paper) on the rate of passage of dosed even-chain $n$-alkanes and found that $\mathrm{C}_{32} n$-alkane absorbed into shredded paper was the marker with narrowest range of diurnal variation of faecal concentrations in goats, when compared with $\mathrm{C}_{24}$ or $\mathrm{C}_{30}$ dosed into cellulose powder, $\mathrm{C}_{26}$ in paper bungs and $\mathrm{C}_{28}$ in Gilson paper filters.
A previous report by these authors (Giráldez et al., 1997) showed that shredded paper pellets had a longer retention time in the gut $(41.8 \mathrm{~h})$ than other matrices such as paper filters $(35.7 \mathrm{~h})$, bungs $(37.6 \mathrm{~h})$ and cellulosepowder capsules $(31.6 \mathrm{~h}$ or $32.6 \mathrm{~h})$. These results confirm the statement of Sibbald et al. (2000) that shredded paper pellets assure a proper dispersion of the external marker in the digesta in animals fed with a fibrous diet with long rumen retention time.

However, although the dosing method (paper pellet matrix) and timing (once-day dosing) applied in this study are the most appropriate for ruminants fed with fibrous diets, as proposed by these authors, our results suggest that it could be important that, for every given situation, the daily dose of the synthetic even-chain $n$-alkane and the natural odd-chain $n$-alkane used for intake estimates were similar, in order to assure homogeneous mixing in the rumen.

Also, it must be taken into account that not only the amount but also the intake pattern of both natural and dosed $n$-alkanes could influence the diurnal variation of $n$-alkane faecal excretion and hence the accuracy of intake calculation. This could have special importance when applying the $n$-alkane technique under field conditions, where the timing of dosing schedule (once a day) can be maintained but the feeding pattern (continuous grazing/browsing) is completely different from the situation studied in the present study.

\subsection{Obtaining a representative sample of faeces}

One of the main criteria for faecal marker use is that the daily faecal sample must be representative of total faeces, with respect to faecal marker concentrations, in order to obtain accurate estimates of intake. In indoor experiments, total faeces would clearly provide the most representative samples of faeces, but under field conditions, grab sampling is required. For this reason, in this study the relationships between the concentration of natural and dosed $n$-alkanes and the $n$-alkane pair (natural/dosed) ratios in total faeces samples and in grab samples taken at $0830 \mathrm{~h}(\mathrm{G} 1), 1630 \mathrm{~h}(\mathrm{G} 2)$ and $0030 \mathrm{~h}$ (G3) during a 4 day period, in the low (LF) and high (HF) feeding experiments were studied in order to determine which grab sample was best correlated with total faecal production.

The regression relationships between the content of natural $\left(\mathrm{C}_{23}, \mathrm{C}_{25}, \mathrm{C}_{31}, \mathrm{C}_{33}\right.$ and $\left.\mathrm{C}_{35}\right)$ and dosed $\left(\mathrm{C}_{24}, \mathrm{C}_{32}\right.$ and $\left.\mathrm{C}_{36}\right) n$-alkanes in rectal grab samples and total faeces showed that most of equations differed from the line of equality, that is, their slope differed significantly from one (data not shown). In general, the dosed $n$-alkanes 
behaved differently from the natural $n$-alkanes in showing better correlation, in terms of higher coefficient of determination $\left(r^{2}\right)$, between grab samples and total faeces: $r^{2}$ ranged from 0.80 to 0.99 for dosed $n$-alkanes and from 0.01 to 0.86 for natural $n$-alkanes. This better correlation of dosed $n$-alkanes seems to indicate that synthetic $n$-alkanes, with the same dosing schedule for all animals, presented lower variability between individuals in the diurnal excretion than natural $n$-alkanes, associated with the solid phase of digesta and then more influenced by the individual pattern of feeding or efficiency of digestion. Within the natural $n$-alkanes, those with higher concentrations in the diet and faeces $\left(\mathrm{C}_{31}\right.$ and $\mathrm{C}_{33}$ ) showed the higher coefficients of determination $\left(r^{2}>0.79\right.$ in LF and $r^{2}>0.42$ in HF experiments).

When looking to the $n$-alkane pairs (Table 4 ), for all grab samples (G1, G2, G3) the poorest correlations (lower $\mathrm{r}^{2}$ ) with total faeces were calculated with $\mathrm{C}_{23} / \mathrm{C}_{24}$ and $\mathrm{C}_{35} / \mathrm{C}_{36}$ pairs, those which showed higher diurnal variation in faeces (Fig. 2), while the best regressions were those obtained with the $n$-alkane pairs $\mathrm{C}_{25} / \mathrm{C}_{24}$, $\mathrm{C}_{31} / \mathrm{C}_{32}$ and $\mathrm{C}_{31} / \mathrm{C}_{33}$.

Note that, in general, the best estimate of $n$-alkane pairs in total faeces collection was recorded from grab samples obtained every $24 \mathrm{~h}$, at the time of dosing (G1), where only the regression for the pair $\mathrm{C}_{23} / \mathrm{C}_{24}$ differed from the line of equality, both under low (LF) or high (HF) feeding level. This fact is of special importance because it confirms that when the $n$-alkane technique is to be applied in conditions where a sample of the total faecal production is difficult to obtain, i.e. grazing, a grab sample of around $200 \mathrm{~g} \mathrm{DM}$ obtained once a day may represent the $n$-alkane concentration of the total faecal production and then can be used for intake estimation.

Feeding level did not affect the representativeness of the G1 sample, but in general the coefficients of correlation between grab samples and total faeces decreased when the feeding level increased (Table 4). This could indicate that increasing intake produced higher individual variability in the rate of passage of digesta, and hence in the faecal excretion pattern of natural and dosed markers. This effect seems to be higher in natural alkanes, mainly linked to the solid phase of digesta, and then more exposed to differences in the individual feeding pattern. However, as explained above, the excretion pattern of all alkane pairs was constant and independent of intake level. Thus, the worse relationship between grab and total faeces samples at the high feeding level could be simply a result of sampling procedures, as the grab sample taken for $n$-alkane analysis represents a lower percentage of total faecal production at the higher intake level due to a higher production of faeces.

\section{6. n-Alkane faecal recoveries}

Fig. 3 shows the mean $n$-alkane faecal recoveries in relation to the carbon chain length. There was a general trend of increasing recoveries with increased $n$-alkane

Table 4

Regression relationships for alkane pairs (natural/dosed) ratios between rectal grab samples G1, G2 or G3 (y) and total faeces (x)

\begin{tabular}{|c|c|c|c|c|c|c|c|}
\hline \multirow{3}{*}{$\begin{array}{l}\text { Grab } \\
\text { sample }\end{array}$} & \multirow{3}{*}{$\begin{array}{l}\text { Alkane } \\
\text { pair }\end{array}$} & \multicolumn{6}{|l|}{ Level of feeding } \\
\hline & & \multicolumn{3}{|l|}{ Low (LF) } & \multicolumn{3}{|l|}{ High (HF) } \\
\hline & & Regression slope ${ }^{a}$ & Slope $=1^{b}$ & $r^{2}$ & Regression slope ${ }^{a}$ & Slope $=1^{b}$ & $r^{2}$ \\
\hline \multirow[t]{5}{*}{ G1 (8.30) } & $\mathrm{C}_{23} / \mathrm{C}_{24}$ & $0.852 \pm 0.0566$ & $*$ & 0.362 & $1.171 \pm 0.0532$ & $* *$ & 0.483 \\
\hline & $\mathrm{C}_{25} / \mathrm{C}_{24}$ & $0.967 \pm 0.0236$ & NS & 0.906 & $1.057 \pm 0.0286$ & NS & 0.806 \\
\hline & $\mathrm{C}_{31} / \mathrm{C}_{32}$ & $0.990 \pm 0.0094$ & NS & 0.975 & $0.973 \pm 0.0138$ & NS & 0.921 \\
\hline & $\mathrm{C}_{33} / \mathrm{C}_{32}$ & $1.001 \pm 0.0124$ & NS & 0.908 & $0.996 \pm 0.0149$ & NS & 0.914 \\
\hline & $\mathrm{C}_{35} / \mathrm{C}_{36}$ & $1.047 \pm 0.0601$ & NS & 0.162 & $1.049 \pm 0.0525$ & NS & 0.317 \\
\hline \multirow[t]{5}{*}{ G2 (16.30) } & $\mathrm{C}_{23} / \mathrm{C}_{24}$ & $0.918 \pm 0.0566$ & NS & 0.420 & $1.298 \pm 0.0638$ & $* * *$ & 0.227 \\
\hline & $\mathrm{C}_{25} / \mathrm{C}_{24}$ & $1.004 \pm 0.0174$ & NS & 0.940 & $1.104 \pm 0.0155$ & $* * *$ & 0.932 \\
\hline & $\mathrm{C}_{31} / \mathrm{C}_{32}$ & $1.027 \pm 0.0055$ & $* * *$ & 0.991 & $1.030 \pm 0.0150$ & NS & 0.898 \\
\hline & $\mathrm{C}_{33} / \mathrm{C}_{32}$ & $1.027 \pm 0.0078$ & $* *$ & 0.965 & $1.041 \pm 0.0161$ & $*$ & 0.878 \\
\hline & $\mathrm{C}_{35} / \mathrm{C}_{36}$ & $1.046 \pm 0.0505$ & NS & 0.689 & $1.075 \pm 0.0513$ & NS & 0.412 \\
\hline \multirow[t]{5}{*}{ G3 (00.30) } & $\mathrm{C}_{23} / \mathrm{C}_{24}$ & $0.858 \pm 0.0406$ & $* *$ & 0.735 & $1.208 \pm 0.0692$ & $*$ & 0.280 \\
\hline & $\mathrm{C}_{25} / \mathrm{C}_{24}$ & $0.961 \pm 0.0152$ & $*$ & 0.959 & $1.0041 \pm 0.0126$ & NS & 0.933 \\
\hline & $\mathrm{C}_{31} / \mathrm{C}_{32}$ & $1.012 \pm 0.0051$ & $*$ & 0.993 & $0.963 \pm 0.0092$ & $* *$ & 0.951 \\
\hline & $\mathrm{C}_{33} / \mathrm{C}_{32}$ & $1.002 \pm 0.0092$ & NS & 0.959 & $0.968 \pm 0.0086$ & $* *$ & 0.958 \\
\hline & $\mathrm{C}_{35} / \mathrm{C}_{36}$ & $0.937 \pm 0.0273$ & $*$ & 0.831 & $1.024 \pm 0.0541$ & NS & 0.252 \\
\hline
\end{tabular}

\footnotetext{
${ }^{a}$ Regressions constrained through zero, since $y$-intercepts of unconstrained regressions did not differ significantly from zero.

b $T$-test for hypothesis that slope $=1$. If no significant (NS) constrained regressions did not differ from equality $(x=y)$.

* $p<0.05 ; * * \quad p<0.01 ; * * * \quad p<0.001$.
} 


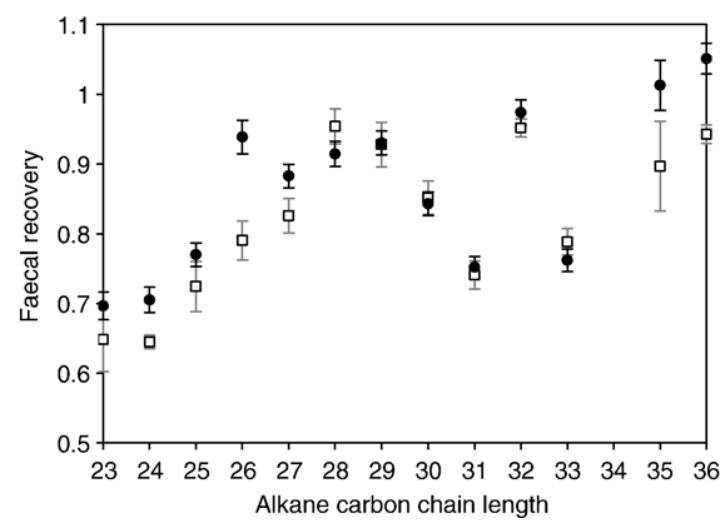

Fig. 3. Influence of the $n$-alkane carbon chain length on faecal recoveries at the low $(\square)$ and high (@) feeding level (means \pm S.E.M.).

chain length, as found in most of previous studies performed with sheep (Mayes et al., 1986), goats (Ferreira et al., 2005) and dairy cattle (Dillon and Stakelum, 1989). However, $n$-alkanes $\mathrm{C}_{30}, \mathrm{C}_{31}$ and $\mathrm{C}_{33}$ did not follow this tendency and showed lower faecal recoveries than those expected for its carbon chain length.

A crucial assumption when using the double $n$-alkane method is that the adjacent $n$-alkanes used in the calculation of intake have similar recoveries. Different authors (Mayes et al., 1986; Dillon and Stakelum, 1989; Stakelum and Dillon, 1990; Dove et al., 2000, 2002) have evaluated the suitability of different odd- and evenchain $n$-alkane pairs for estimating intake and in most of these studies, $n$-alkane pairs $\mathrm{C}_{31} / \mathrm{C}_{32}$ and $\mathrm{C}_{33} / \mathrm{C}_{32}$ showed the lower discrepancy in faecal recoveries and hence have been proposed to estimate intake. In this work, the faecal recoveries of $\mathrm{C}_{32}(0.95 \mathrm{in} \mathrm{LF}$ and 0.97 in $\mathrm{HF}$ trials) were greater than those measured for $\mathrm{C}_{31}(0.74$ in $\mathrm{LF}$ and 0.75 in HF) and $\mathrm{C}_{33}(0.79$ in $\mathrm{LF}$ and 0.76 in $\mathrm{HF})$. The same was observed for $\mathrm{C}_{36}(0.94 \mathrm{in} \mathrm{LF}$ and 1.05 in HF) compared to $\mathrm{C}_{35}$ ( 0.90 in LF and 1.02 in HF). These results are in agreement with the statement made by Dove and Mayes (1991) that in some occasions the dosed $n$-alkanes may present higher faecal recoveries than adjacent natural $n$-alkanes, although they described lower discrepancies between the faecal recoveries of natural and dosed $n$-alkanes than those obtained in this study. The higher recoveries of dosed $n$-alkanes $\mathrm{C}_{32}$ and $\mathrm{C}_{36}$ relative to those of the adjacent odd-chain $n$-alkanes could in part be produced by differences of digestive kinetics between synthetic $n$-alkanes adsorbed onto paper pellets compared to natural $n$-alkanes present in the cuticular wax. In fact, Mayes et al. (1988) observed that 0.3 to 0.4 of the dosed $n$-alkanes associate with the liquid phase of the digesta, contrary to the association of the natural $n$-alkanes with the solid phase. This could be the reason that in some occasions the faecal recovery of dosed $n$-alkanes is greater than might be expected from interpolation between adjacent natural $n$-alkanes. In a previous study, performed with cattle, Hendricksen et al. (2002) found that faecal recoveries of dosed $C_{32}$ were 0.03 to 0.26 greater than those of $\mathrm{C}_{31}$ and $\mathrm{C}_{33}$, respectively. Our results show even higher differences, as we found that $\mathrm{C}_{32}$ recoveries were 0.28 to 0.29 greater than for $\mathrm{C}_{31}$ and 0.21 to 0.28 greater than those of $\mathrm{C}_{33}$ in the low and high feeding trials, respectively. Dove et al. (2002) in sheep reported faecal recoveries of dosed $\mathrm{C}_{28}$ 0.18 and 0.16 greater than for $\mathrm{C}_{27}$ and $\mathrm{C}_{29}$, respectively, although they detected only small differences between dosed $\mathrm{C}_{32}$ and natural $\mathrm{C}_{31}$ or $\mathrm{C}_{33}$.

It must be noted that, from data shown in Fig. 3, it seems that faecal recoveries of dosed $n$-alkanes $C_{32}$ and $\mathrm{C}_{36}$ were quite consistent with their chain lengths, while natural $n$-alkanes $\mathrm{C}_{31}$ and $\mathrm{C}_{33}$ had surprisingly lower faecal recoveries than expected, both at the low and high intake level. It has been previously described that in some situations, not only the dosed $n$-alkanes but also the plant $n$-alkanes differ from the general curvilinear relation between faecal recovery and chain length. Brosh et al. (2003) working with goats, cows and calves found that faecal recoveries for natural even-chain $n$-alkanes differed from the pattern of natural odd-chain $n$-alkanes and Elwert et al. (2004) in sheep reported slightly higher faecal recoveries of natural even-chain $n$-alkanes $\mathrm{C}_{28}$ and $\mathrm{C}_{30}$ than adjacent odd-chained $n$-alkanes. To date, there are no explanations for such differences between natural and dosed $n$-alkanes in some experiments, although they probably arise from the use of certain animals, diets and/or intake levels.

In this study, the effect of feeding level (LF or HF) on the $n$-alkane faecal recoveries and the resultant accuracy of the $n$-alkane technique has been studied, although this effect could be confounded if these results were affected by the experimental period. To avoid this, different feeding levels (low and high) should have been applied during the same time, in order to assure that conditions were similar. However, because both experiments (LF and HF) were conducted immediately one behind the other, in metabolic cages with the same conditions, with the same animals and giving the same food, in terms of chemical composition (Table 1 ) and $n$-alkane concentrations (Table 2), the effect "period" was assumed as negligible and the $n$-alkane faecal recoveries and intake estimates were subjected to analysis of variance with feeding level and animal as fixed effects. Table 5 shows the effect of feeding level on the $n$-alkane faecal recoveries. The animal effect was not significant. For 
Table 5

Effect of feeding level on the $n$-alkane faecal recoveries

\begin{tabular}{|c|c|c|c|c|c|c|}
\hline \multirow[t]{3}{*}{ Marker } & \multicolumn{4}{|c|}{ Level of feeding } & \multirow[t]{3}{*}{ S.E.M. } & \multirow[t]{3}{*}{ Significance } \\
\hline & \multicolumn{2}{|c|}{ Low (LF) } & \multicolumn{2}{|c|}{ High (HF) } & & \\
\hline & Mean & $\mathrm{CV}$ & Mean & $\mathrm{CV}$ & & \\
\hline $\mathrm{C}_{23}$ & 0.648 & 23.6 & 0.697 & 9.3 & 0.0354 & NS \\
\hline $\mathrm{C}_{24}$ & 0.645 & 5.0 & 0.705 & 8.4 & 0.0145 & $* *$ \\
\hline $\mathrm{C}_{25}$ & 0.724 & 16.7 & 0.770 & 7.1 & 0.0283 & NS \\
\hline $\mathrm{C}_{26}$ & 0.791 & 11.9 & 0.938 & 8.4 & 0.0261 & $* * *$ \\
\hline $\mathrm{C}_{27}$ & 0.826 & 10.2 & 0.883 & 6.6 & 0.0218 & NS \\
\hline $\mathrm{C}_{28}$ & 0.954 & 8.6 & 0.914 & 6.7 & 0.0219 & NS \\
\hline $\mathrm{C}_{29}$ & 0.928 & 11.3 & 0.930 & 6.0 & 0.0253 & NS \\
\hline $\mathrm{C}_{30}$ & 0.852 & 9.5 & 0.843 & 6.7 & 0.0211 & NS \\
\hline $\mathrm{C}_{31}$ & 0.741 & 9.0 & 0.752 & 6.6 & 0.0177 & NS \\
\hline $\mathrm{C}_{32}$ & 0.952 & 4.5 & 0.974 & 6.2 & 0.0159 & NS \\
\hline $\mathrm{C}_{33}$ & 0.788 & 8.0 & 0.762 & 7.0 & 0.0176 & NS \\
\hline $\mathrm{C}_{35}$ & 0.897 & 23.8 & 1.013 & 9.6 & 0.0523 & NS \\
\hline $\mathrm{C}_{36}$ & 0.943 & 4.7 & 1.051 & 6.8 & 0.0180 & $* * *$ \\
\hline
\end{tabular}

$\mathrm{CV}$ : coefficient of variation.

S.E.M.: standard error of means.

** $p<0.01$; *** $p<0.001$.

most $n$-alkanes, a general tendency of recoveries to be lower at the lower feeding level was observed, although this effect was significant only on the faecal recoveries of two dosed $n$-alkanes $\left(\mathrm{C}_{24}\right.$ and $\left.\mathrm{C}_{36}\right)$ and one natural $n$ alkane $\left(\mathrm{C}_{26}\right)$. These results seems to indicate that the $n$ alkane absorption in the digestive tract tended to be higher, and hence the faecal recoveries lower, as the rate of passage of digesta decreased due to a lower intake level (LF experiment). These results agree with previous findings of Unal and Garnsworthy (1999) in dairy cattle, who described a tendency of faecal recoveries of $n$ alkanes $\mathrm{C}_{32}, \mathrm{C}_{33}$ and $\mathrm{C}_{36}$ to be lower when animals received a daily diet of $20 \mathrm{~kg}$ silage compared with diets of 25 or $30 \mathrm{~kg}$ silage, although these differences were not significant. Similar results were described in sheep by Dove et al. (2002), who found lower faecal recoveries when animals received $600 \mathrm{~g} \mathrm{DM} /$ day compared to those eating $1200 \mathrm{~g} \mathrm{DM} /$ day, the difference being significant for some odd chain $n$-alkanes (from $\mathrm{C}_{25}$ to $\mathrm{C}_{31}$ ). In contrast, in dairy cows, Ohajuruka and Palmquist (1991) found that faecal recovery of $\mathrm{C}_{31}$ decreased with increasing intake. Nevertheless, Mayes et al. (1986, 1988), Dove and Oliván (1998) and Elwert et al. (2004) did not find significant effect of the level of feeding on the $n$-alkane faecal recoveries in sheep.

It should be noticed the high faecal recoveries obtained for $\mathrm{C}_{35}$ (1.01) and $\mathrm{C}_{36}$ (1.05) in the HF experiment (Table 5), although this probably was caused by a likely analytical bias due to the low concentrations of these $n$-alkanes in diet and faeces and not by a synthesis of $n$-alkanes in the intestinal tract.
An important factor that may influence the $n$-alkane faecal recoveries is individual variability, which has been described in cattle (Hendricksen et al., 2002), sheep (Valiente et al., 2003) and goats (Ferreira et al., 2005). We should point out that in this study the lower intake level led to higher individual variability (expressed as CV, Table 5) in the faecal recovery of natural $n$-alkanes, which seems to indicate that the individual differences in the digestive efficiency were more evident at the lower intake level. Moreover, at the low feeding level, the individual variability of faecal recoveries of the natural $n$-alkanes seemed to relate with the $n$-alkane chain length, as described by Ferreira et al. (2005) in goats. In fact, in the LF experiment, $\mathrm{CVs}$ were higher for short chain $n$-alkanes $\left(\mathrm{C}_{23}\right.$ to $\left.\mathrm{C}_{29}\right)$ than for long chain $n$-alkanes $\left(\mathrm{C}_{30}\right.$ to $\left.\mathrm{C}_{33}\right)$, with the exception of $\mathrm{C}_{35}$, with extremely high $\mathrm{CV}$ (23.8), probably due to a higher analytical error related with its low concentration.

However, the level of intake did not affect individual variability of the faecal recoveries of dosed $n$-alkanes $\left(\mathrm{C}_{24}\right.$, $\mathrm{C}_{32}$ and $\mathrm{C}_{36}$ ) which remained more stable. This observation again suggests that natural and dosed $n$-alkanes show different behaviour in the digestive tract, which should be investigated more deeply as it could have important consequences for the accuracy of intake estimates.

\subsection{Intake estimates}

Table 6 shows the comparison between the mean measured intake and that estimated using the different $n$ -

Table 6

Herbage intake estimates (E, means \pm S.E.M.) and differences between estimated and observed ( $\mathrm{E}-\mathrm{O}$ ) intake obtained with $\mathrm{C}_{23} / \mathrm{C}_{24}, \mathrm{C}_{25} / \mathrm{C}_{24}$, $\mathrm{C}_{31} / \mathrm{C}_{32}, \mathrm{C}_{33} / \mathrm{C}_{32}$ and $\mathrm{C}_{35} / \mathrm{C}_{36}$ alkane pairs in the low feeding (LF) and high feeding (HF) experiments

\begin{tabular}{cllcll}
\hline $\begin{array}{l}\text { Feeding } \\
\text { level }\end{array}$ & $\begin{array}{l}\text { Alkane } \\
\text { pair }\end{array}$ & E (kg DM) & $\begin{array}{l}\mathrm{E}-\mathrm{O} \\
(\mathrm{g} \mathrm{DM})\end{array}$ & $\begin{array}{l}P \\
\text { value }^{\mathrm{a}}\end{array}$ & $r^{2(\mathrm{~b})}$ \\
\hline $\mathrm{LF}: 1.057$ & $\mathrm{C}_{23} / \mathrm{C}_{24}$ & $1.059 \pm 0.0693$ & +1.5 & 0.984 & $0.397^{(*)}$ \\
$\mathrm{kg} /$ day & $\mathrm{C}_{25} / \mathrm{C}_{24}$ & $1.185 \pm 0.0496$ & +127.9 & 0.037 & $0.743^{(* * *)}$ \\
& $\mathrm{C}_{31} / \mathrm{C}_{32}$ & $0.802 \pm 0.0149$ & -255.5 & 0.000 & $0.612^{(* *)}$ \\
& $\mathrm{C}_{33} / \mathrm{C}_{32}$ & $0.859 \pm 0.0212$ & -198.2 & 0.000 & $0.177^{(\mathrm{NS})}$ \\
& $\mathrm{C}_{35} / \mathrm{C}_{36}$ & $1.009 \pm 0.0765$ & -48.6 & 0.542 & $0.004^{(\mathrm{NS})}$ \\
$\mathrm{HF}: 1.716$ & $\mathrm{C}_{23} / \mathrm{C}_{24}$ & $1.710 \pm 0.0754$ & -6.5 & 0.930 & $0.138^{(\mathrm{NS})}$ \\
$\mathrm{kg} /$ day & $\mathrm{C}_{25} / \mathrm{C}_{24}$ & $1.882 \pm 0.0396$ & +165.5 & 0.001 & $0.197^{(\mathrm{NS})}$ \\
& $\mathrm{C}_{31} / \mathrm{C}_{32}$ & $1.276 \pm 0.0209$ & -440.3 & 0.000 & $0.374^{(*)}$ \\
& $\mathrm{C}_{33} / \mathrm{C}_{32}$ & $1.295 \pm 0.0228$ & -421.4 & 0.000 & $0.320^{(\mathrm{NS})}$ \\
& $\mathrm{C}_{35} / \mathrm{C}_{36}$ & $1.664 \pm 0.0705$ & -52.6 & 0.427 & $0.426^{(*)}$ \\
\hline
\end{tabular}

${ }^{\text {a }} P$ value for hypothesis of no difference between estimated and observed values.

b Significance of correlation of individual data.

** $p<0.01 ; * * * \quad p<0.001$. 
alkane pairs in the low (LF) and high (HF) feeding conditions. In the LF experiment, with a mean feeding level of $1.057 \mathrm{~kg} / 100 \mathrm{~kg} \mathrm{LW}$, there were no significant differences between the mean observed $(\mathrm{O})$ and estimated (E) daily intakes when $\mathrm{C}_{23} / \mathrm{C}_{24}(\mathrm{E}-\mathrm{O}=$ $+1.5 \mathrm{~g} ; P=0.984)$ and $\mathrm{C}_{35} / \mathrm{C}_{36}(\mathrm{E}-\mathrm{O}=-48.6 \mathrm{~g}$; $P=0.542) n$-alkane pairs were used, although the correlation of individual estimated and observed intakes was significant $(P<0.05)$ only when using the $\mathrm{C}_{23} / \mathrm{C}_{24}$ pair. However, calculations based on the $n$-alkane pair $\mathrm{C}_{25} / \mathrm{C}_{24}$ overestimated significantly $(P=0.037)$ intake by $128 \mathrm{~g} \mathrm{DM} /$ day and those based on pairs $\mathrm{C}_{31} / \mathrm{C}_{32}$ and $\mathrm{C}_{33} /$ $\mathrm{C}_{32}$ underestimated intake (256 and $198 \mathrm{~g} \mathrm{DM} /$ day, respectively). These results rise from the discrepancies between the faecal recoveries of natural and dosed $n$-alkanes of each $n$-alkane pair (Table 5). For the pair $\mathrm{C}_{25} / \mathrm{C}_{24}$, as the faecal recovery of the natural $n$-alkane $\left(\mathrm{C}_{25}\right)$ was 0.12 greater than that of the dosed $n$-alkane $\left(\mathrm{C}_{24}\right)$, intake was 0.12 overestimated. In the contrary, when faecal recoveries of natural $n$-alkanes $\left(\mathrm{C}_{31}, \mathrm{C}_{33}\right)$ were lower ( 0.22 and 0.20 , respectively) than that of the dosed $n$-alkane $\left(\mathrm{C}_{32}\right)$, intake was underestimated $(0.24$ and 0.19 , respectively). The best coefficient of determination $\left(r^{2}\right)$ between estimated and observed values was obtained with the $n$-alkane pair $\mathrm{C}_{25} / \mathrm{C}_{24}\left(r^{2}=0.74\right.$, $P<0.001$ ), although the calculation of the mean intake was overestimated, as stated before.

When the daily intake was increased to $1.716 \mathrm{~kg} /$ $100 \mathrm{~kg} \mathrm{LW}$ (HF trial), the $n$-alkane pair $\mathrm{C}_{23} / \mathrm{C}_{24}$ gave the best estimate of intake, with a discrepancy of only $6.5 \mathrm{~g} /$ day, although the correlation between estimated and observed values was not significant and explained only $14 \%$ of individual variability. In this experiment, the $n$-alkane pair $\mathrm{C}_{25} / \mathrm{C}_{24}$ overestimated intake $(0.10)$ due to the fact that $\mathrm{C}_{25}$ had a faecal recovery 0.09 greater than $\mathrm{C}_{24}$. However, $n$-alkane pairs $\mathrm{C}_{31} / \mathrm{C}_{32}$ and $\mathrm{C}_{33} / \mathrm{C}_{32}$ underestimated intake $(0.26$ and 0.25 , respectively) because the faecal recovery of the dosed $\mathrm{C}_{32}$ was 0.23 and 0.22 higher than the natural $n$-alkanes $C_{31}$ and $\mathrm{C}_{33}$. The best correlation between observed and estimated intakes was obtained with the $n$-alkane pair $\mathrm{C}_{35} / \mathrm{C}_{36} \quad(r=0.65)$, which showed lower variability between individuals.

These results confirm that for the $n$-alkane technique to give an accurate estimate of intake, the natural and dosed $n$-alkanes must show similar faecal recoveries. This condition was met by the $n$-alkane pairs $\mathrm{C}_{23} / \mathrm{C}_{24}$ and $\mathrm{C}_{35} / \mathrm{C}_{36}$, which gave accurate estimates of the treatment average intake in both feeding levels, although they showed the poorest characteristics as digestive marker pairs in terms of higher variation of diurnal excretion, lower representativeness of faecal grab samples and higher individual variability of faecal recoveries of the natural $n$-alkane $\left(\mathrm{C}_{23}\right.$ or $\left.\mathrm{C}_{35}\right)$, which could be in part due to analytical bias caused by their extremely low concentration in the diet and faeces. However, the $n$-alkane pairs $\mathrm{C}_{31} / \mathrm{C}_{32}$ and $\mathrm{C}_{33} / \mathrm{C}_{32}$ complied with the main rules of digestive markers, as they followed a very constant diurnal pattern of faecal excretion and hence a consistent ratio of dosed to natural $n$-alkane in faeces, but they showed the greatest deviation of intake estimates, due to high discrepancy between the faecal recoveries of natural and dosed $n$-alkanes.

As a whole, the data show that the accuracy of intake estimates depends on the similarity of faecal recoveries of natural and dosed $n$-alkanes used for calculations. In discussing this aspect, Dove and Mayes (1996) showed that a given proportional difference in the faecal recovery of the natural and dosed $n$-alkanes should result in an equivalent proportional error in the estimate of intake. In support of this, we found a strong correlation $\left(r^{2}=0.995\right)$ between the variation in the recoveries of the $n$-alkane pairs used to estimate intake and the variation in accuracy of the estimate of intake (Fig. 4). This also agrees with results of Hendricksen et al. (2002) in Brahman-cross cattle fed with low quality tropical diets. In our study, feeding level did not affect this relationship. In both experiments, the magnitude of the difference in recoveries between the two $n$-alkanes used to estimate intake, corresponded significantly $(P<0.001)$ to the accuracy of the intake estimates.

The accuracy of any biological assay is a function of many factors, including analytical errors, techniques to ensure collection of representative samples and inherent animal to animal variability. For intake assays, Heaney

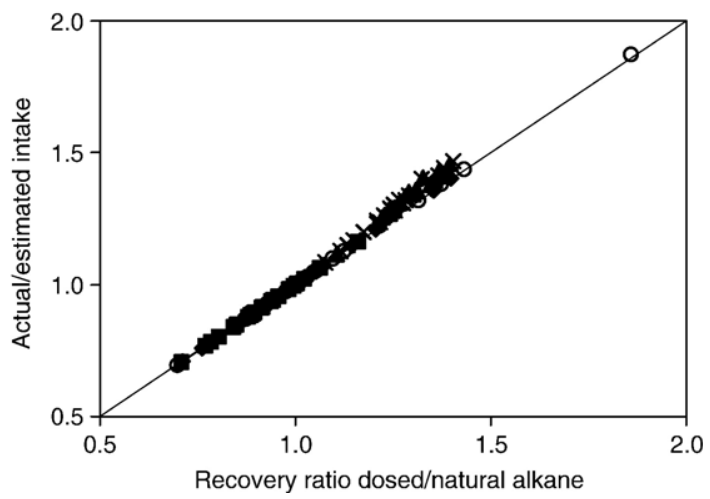

Fig. 4. Relationship between the recovery ratio dosed/natural alkane and the resultant ratio actual/estimated intake ( $\bullet: \mathrm{C}_{23} / \mathrm{C}_{24}, \mathbf{\square}: \mathrm{C}_{25} / \mathrm{C}_{24}$, $\left.\boldsymbol{\Delta}: \mathrm{C}_{31} / \mathrm{C}_{32}, \times: \mathrm{C}_{33} / \mathrm{C}_{32}, \mathrm{O}: \mathrm{C}_{35} / \mathrm{C}_{36}\right)$. Solid line is the line of equality $(y=x)$. 
(1979) proposed individual variability as the major factor determining the ultimate accuracy that can be attained. Our findings confirm that in beef cattle the individual variability of $n$-alkane faecal recoveries may be a problem if individual estimates of intake are wanted. None of the $n$-alkane pairs tested in this study $\left(\mathrm{C}_{23} / \mathrm{C}_{24}\right.$, $\mathrm{C}_{25} / \mathrm{C}_{24}, \mathrm{C}_{31} / \mathrm{C}_{32}, \mathrm{C}_{33} / \mathrm{C}_{32}, \mathrm{C}_{35} / \mathrm{C}_{36}$ ) complied with the required conditions to allow accurate individual estimates of intake: those alkane pairs with similar faecal recoveries $\left(\mathrm{C}_{23} / \mathrm{C}_{24}\right.$ and $\left.\mathrm{C}_{35} / \mathrm{C}_{36}\right)$ gave accurate estimates of average intake but showed high individual variability in the faecal recovery of the natural $n$-alkane and consequently in the individual discrepancies between estimated and observed intakes; while those with high correlation between estimated and observed individual intakes $\left(\mathrm{C}_{31} / \mathrm{C}_{32}\right.$ and $\mathrm{C}_{33} / \mathrm{C}_{32}$ in $\mathrm{LF}$ and $\mathrm{C}_{31} /$ $\mathrm{C}_{32}$ in $\mathrm{HF}$ ) showed notable discrepancies in the faecal recovery of natural and dosed alkanes and hence high deviations of intake estimates.

\section{Conclusions}

The results obtained in this study show that in beef cattle receiving a diet of lucerne hay given in two equal portions daily and dosed once a day with synthetic $n$-alkanes absorbed into paper pellets, the different $n$-alkane pairs used for intake estimates $\left(\mathrm{C}_{23} / \mathrm{C}_{24}\right.$, $\left.\mathrm{C}_{25} / \mathrm{C}_{24}, \mathrm{C}_{31} / \mathrm{C}_{32}, \mathrm{C}_{33} / \mathrm{C}_{32}, \mathrm{C}_{35} / \mathrm{C}_{36}\right)$ reach a steady state in faeces in a 5-day period. For this dosing procedure, one faeces sample obtained at the dosing time is representative of the daily faecal marker concentration, which simplifies the use of the $n$-alkane technique in grazing conditions. $n$-Alkane recoveries were in general lower at the low feeding level, although this difference was significant only for 3 of $13 n$-alkanes. Also, the lower feeding level produced an increase of the individual variability of natural $n$-alkane recoveries.

In both feeding levels, the $n$-alkane pairs $\mathrm{C}_{23} / \mathrm{C}_{24}$ and $\mathrm{C}_{35} / \mathrm{C}_{36}$ gave accurate estimates of the treatment average intake, although the faecal recoveries of the natural $n$-alkane $\left(\mathrm{C}_{23}\right.$ or $\left.\mathrm{C}_{35}\right)$ showed high individual variability. However, the $n$-alkane pairs $\mathrm{C}_{31} / \mathrm{C}_{32}$ and $\mathrm{C}_{33} /$ $\mathrm{C}_{32}$ gave the greatest deviations of intake estimates, because the dosed $n$-alkanes $\left(\mathrm{C}_{32}\right.$ and $\left.\mathrm{C}_{36}\right)$ presented higher faecal recoveries than those of the adjacent oddchain $n$-alkanes $\left(\mathrm{C}_{31}, \mathrm{C}_{33}\right.$ and $\left.\mathrm{C}_{35}\right)$. This discrepancy may be situation dependent, that is, it could depends on the animal (species, breed, age, size) and food (feeding level, diet composition) characteristics. For this reason, the use of the $n$-alkane technique to estimate intake should be preceded by a calculation of the actual $n$-alkane recoveries for any given situation.

\section{Acknowledgments}

The authors would like to thank to the staff of Livestock Production Systems of SERIDA for skilled management of animals and samples and particularly to M.J. Martínez and M. Mocha for technical assistance on $n$-alkane extraction and analysis.

\section{References}

AOAC, 1990. Official Methods of Analysis, 14th ed. Association of Official Analytical Chemists, Washington DC.

AFRC, 1993. Technical committee on responses to nutrients, report no. 5. Nutritive requirements of ruminant animals. Energy Nutr. Abs. Rev., Series B 60, 729-824.

Brosh, A., Henkin, Z., Rothman, S.J., Aharoni, Y., Orlov, A., Arieli, A., 2003. Effects of faecal $n$-alkane recovery in estimates of diet composition. J. Agric. Sci. 140, 93-100.

Dillon, P., Stakelum, G., 1989. Herbage and dosed alkanes as a grass measurements technique for dairy cows. Ir. J. Agric. Res. 28, 104 (Abstr.).

Dove, H., Mayes, R.W., Freer, M., Coombe, J.B., 1989. Faecal recoveries of the alkanes of plant cuticular waxes in penned and in grazing sheep. Proc. XVI Int. Grasslds. Cong., Nice, France, pp. 1093-1094.

Dove, H., Mayes, R.W., 1991. The use of plant wax alkanes as markers substances in studies of the nutrition of herbivores: a review. Aust. J. Agric. Res. 42, 913-957.

Dove, H., Mayes, R.W., 1996. Plant wax components: a new approach to estimating intake and diet composition in herbivores. J. Nutr. 126, $13-26$.

Dove, H., Oliván, M., 1998. Using synthetic or beeswax alkanes for estimating supplement intake in sheep. Anim. Prod. Aust., Proc. Aust. Soc. Anim. Prod. Bienn. Conf. 22, 189-192.

Dove, H., Freer, M., Foot, J.Z., 2000. The nutrition of grazing ewes during pregnancy and lactation: a comparison of alkane-based and chromium/in vitro-based estimates of herbage intake. Aust. J. Agric. Res. 51, 765-777.

Dove, H., Mayes, R.W., Lamb, C.S., Ellis, K.J., 2002. Factors influencing the release rate of alkanes from an intra-ruminal, controlled-release device, and the resultant accuracy of intake estimation in sheep. Aust. J. Agric. Res. 53, 681-696.

Elwert, C., Kluth, H., Rodehutscord, M., 2004. Effect of variable intake of alfalfa and wheat on faecal alkane recoveries and estimates of roughage intake in sheep. J. Agric. Sci. 142, 213-223.

Ferreira, L.M.M., Oliván, M., Rodrigues, M.A.M., Garcia, U., Osoro, K., 2005. Validation of the alkane technique to estimate diet selection of goats grazing heather-gorse vegetation communities. J. Sci. Food Agric. 85, 1636-1646.

Giráldez, F.J., Mayes, R.W., Lamb, C.S., 1997. Estudio de los alcanos sintéticos de cadena par como marcadores para estimar el ritmo de paso de los alimentos. ITEA, Prod. Anim. 18 (Suppl 1), $13-15$.

Giráldez, F.J., Lamb, C.S., Lopez, S., Mayes, R.W., 2004. Effects of carrier matrix and dosing frequency on digestive kinetics of evenchain alkanes and implications on herbage intake and rate of passage studies. J. Sci. Food Agric. 84, 1562-1570.

Heaney, D.P., 1979. Sheep as pilot animals. Proc. of the Workshop Standardization of Analytical Methodology for Feeds, Ottawa, Canada, pp. 44-48. 
Hendricksen, R.E., Reich, M.M., Roberton, R.F., Reid, D.J., Gazzola, C., Rideout, J.A., Hill, R.A., 2002. Estimating the voluntary intake and digestibility of buffel-grass and lucerne hays offered to Brahman-cross cattle using $n$-alkanes. Anim. Sci. 74, 567-577.

Mayes, R.W., Dove, H., 2000. Measurements of dietary nutrient intake in free-ranging mammalian herbivores. Nutr. Res. Rev. 13, 107-138.

Mayes, R.W., Lamb, C.S., Colgrove, P.M., 1986. The use of dosed and herbage $n$-alkanes as markers for the determination of herbage intake. J. Agric. Sci. 107, 161-170.

Mayes, R.W., Lamb, C.S., Colgrove, P.M., 1988. Digestion and metabolism of dosed even-chain and herbage odd-chain $n$-alkanes in sheep. Proc. 12th Gen. Meeting Eur. Grasslds Fed, pp. 159-163.

Malossini, F., Piasentier, E., Bovolenta, S., 1990. n-Alkane content of some forages. J. Sci. Food Agric. 3, 405-409.

Molina, D.O., Matamoros, I., Pell, A.N., 2004. Accuracy of estimates of herbage intake of lactating cows using alkanes: comparison of two types of capsules. Anim. Feed Sci. Technol. 114, 241-260.

Ohajuruka, O.A., Palmquist, D.L., 1991. Evaluation of $n$-alkanes as digesta markers in dairy cows. J. Anim. Sci. 69, 1726-1732.

Oliván, M., Osoro, K., 1999. Effect of temperature on alkane extraction from faeces and herbage. J. Agric. Sci. 132, 305-312.

Owens, F.N., Hanson, C.F., 1992. External and internal markers for appraising site and extent of digestion in ruminants. J. Dairy Sci. $75,2605-2617$.
Robertson, J.B., Van Soest, P.J., 1981. The detergent system of analysis and its application in human foods. The Analysis of Dietary Fiber in Food. Marcell Dekker Inc., New York, pp. 123-158.

Sibbald, A.M., Davidson, G.C., Mayes, R.W., 2000. Effect of dosing regime on intake estimation using the $n$-alkane technique in sheep fed pelleted grass meal. J. Sci. Food Agric. 80, 1206-1210.

Stakelum, G., Dillon, P., 1990. Dosed and herbage alkanes as feed intake predictors with dairy cows: the effect of feeding level and frequency of perennial ryegrass. Proc. VIIth European Grazing Workshop, Wageningen, Netherlands, Paper, vol. W4.

SPSS 11.5, 2002. Guía breve. SPSS Inc., Ireland.

Unal, Y., Garnsworthy, P.C., 1999. Estimation of intake and digestibility of forage-based diets in group-fed dairy cows using alkane as markers. J. Agric. Sci. 133, 419-425.

Van Soest, P.J., Robertson, J.B., Lewis, B.A., 1991. Methods for dietary fiber, neutral detergent fiber, and nonstarch polysaccharides in relation to animal nutrition. J. Dairy Sci. 74, 3583-3597.

Valiente, O.L., Delgado, P., de Vega, A., Guada, J.A., 2003. Validation of the $n$-alkane technique to estimate intake, digestibility, and diet composition in sheep consuming mixed grain:roughage diets. Aust. J. Agric. Res. 54, 693-702. 